\title{
Pengembangan Media Pembelajaran Laboratorium Virtual untuk Mengatasi Miskonsepsi Pada Materi Fisika Inti di SMAN 1 Binamu, Jeneponto
}

\author{
Ahmad Swandi", Siti Nurul Hidayah.LJ, Irsan \\ Universitas Negeri Makassar \\ Jalan Daeng Tata Raya, Makassar 90223 \\ Email: ahmadswandii@gmail.com, Fax.+62411840622
}

\begin{abstract}
Abstrak - Telah dilakukan penelitian dan pengembangan media pembelajaran laboratorium virtual yang bertujuan untuk mengatasi miskonsepsi peserta didik materi fisika inti dan radioaktivitas Subjek uji coba adalah peserta didik kelas XII IPA SMA Binamu berjumlah 30 orang. Prosedur pengembangannya menggunakan model Four-D terdiri dari tahap pendefinisian, perancangan, dan pengembangan. Hasil penelitian menunjukkan (1) media laboratorium virtual model presentasi dan tutorial pada materi aktivitas zat radioaktif dan daya tembus sinar radioaktif diperoleh hasil valid dan reliabel. Setiap tampilan dilengkapi navigasi, petunjuk, hyperlink,dan fasilitas lainnya untuk memudahkan penggunaan program, (2) perangkat pembelajaran berupa Rencana Pelaksanaan Pembelajaran, Buku Bacaan, dan Lembar Kerja Peserta Didik selain dibuat dalam bentuk hardcopy, juga softcopy autorun CD. Penilaian menunjukkan valid dan reliabel, (3) aktivitas peserta didik di atas $85 \%$, menunjukkan pembelajaran yang dilakukan mampu mengaktifkan peserta didik. Persentase persepsi peserta didik adalah 93,05\% menunjukkan sangat setuju terhadap pembelajaran fisika berbasis media laboratorium virtual, (4) berdasarkan tes akhir, terjadi peningkatan pemahaman konsep yang baik peserta didik dibandingkan sebelum diberi media laboratorium virtual.
\end{abstract}

Kata kunci: Aktivitas, Laboratorium Virtual, Miskonsepsi, Persepsi

\begin{abstract}
The develovment research of learning instrument of virtual laboratory was conducted which aimed at contending the misconception about nuclear physics. The subject of the study was 30 students grade XII IPA at SMA 1 Binamu,Jeneponto.The procedure of development referred to four-D model consisted of definition phase, design phase, and development phase. The result of the study revealed that (1) the virtual laboratory media developed in form of presentation and tutorial model that consisted of radioactivity-decay and emerge power of radioactive radiation gotten valid and reliable result.each of media display completed with navigation, program instruction, hyperlink and several other facilities to allow users to run the program.(2)the learning instrument in form of lesson plan, the textbook, and student's workbook presented in softcopy of CD autorun.product was valid and reliable. (3) the student's activities during the learning process were above $85 \%$, show that the students agree with instrument physiscs learning basis on virtual laboratory. (4) according to the tes result, the concept comprehension of students was improve than before given virtual laboratory media.
\end{abstract}

Keywords: Activities, virtual laboratory, misconception and perception

\section{PENDAHULUAN}

Masalah terbesar peserta didik dalam pembelajaran adalah kesalahpahaman yang sering muncul ketika mempelajari materi fisika. Hal ini disebabkan karena pendidik hanya mengajarkan fisika yang bersifat abstrak melalui pembelajaran dikelas, tidak dilengkapi dengan proses eksperimen di laboratorium. Rendahnya kualitas pembelajaran fisika ditentukan oleh beberapa faktor, yaitu ketersediaan sarana, alat dan bahan laboratorium untuk pelaksanaan eksperimen.

Untuk mewujudkan proses eksperimen dalam laboratorium, pendidik harus memperhatikan ketersediaan ruangan, bahan dan peralatan. Peserta didik kelas XII SMA sangat sulit memahami konsep fisika terutama dalam memahami konsep materi yng bersifat abstrak. Hal ini disebabkan karena materi ini sangat jarang di eksperimenkan dalam laboratorium disamping peralatan yang sangat mahal dan resiko yang diakibatkan jika terjadi kesalahan dalam eksperimen itu. Oleh karena itu salah satu solusi untuk mengatasi masalah tersebut adalah memamfaatkan media pembelajaran berupa laboratorium virtual. Pemanfaatan laboratorium virtual diharapkan dapat meningkatkan aktivitas peserta didik sehingga pembelajaran menjadi lebih mudah, menarik dan interaktif dan mampu mendorong motivasi peserta didik untuk mempelajari materi ini baik secara individu maupun kelompok.

Penelitian ini dilakukan untuk menjawab masalah-masalah berikut:

a. Bagaimana aktivitas dan persepsi peserta didik terhadap pembelajaran berbasis laboratorium virtual

b. Bagaimanakah karakteristik perangkat pembelajaran berbasis media laboratorium virtual pada materi fisika inti?

c. Apakah media pembelajaran berbasis laboratorium virtual mampu mengatasi masalah miskonsepsi peserta didik pada materi fisika inti?

\section{LANDASAN TEORI}

A. Media Pembelajaran

Media pembelajaran didefinisikan sebagai alat bantu berupa fisik maupun nonfisik yang digunakan sebagai perantara antara guru dan peserta didik dalam memahami materi pelajaran secara lebih efektif dan efisien. Menurut Gundogdu, et. al., (2011) melalui media komputer, materi 
pelajaran dapat lebih cepat diterima peserta didik secara utuh serta menarik minat mereka untuk belajar lebih lanjut.

Penggunaan media komputer dalam pembelajaran guru memainkan peran penting sebagai fasilitator untuk meningkatkan pemahaman peserta didik terhadap materi pelajaran (Kutluca, 2010).

\section{B. Laboratorium Virtual}

Mahanta \& Sarma (2012) Laboratorium Virtual (LabVir) memanfaatkan komputeruntuk mensimulasikan sesuatu yang rumit,perangkat percobaan yang mahal atau mengganti percobaan di lingkungan berbahaya. Selanjutnya, Tatli \& Ayas, (2012) bahwa Lab-Vir sebagai faktor pendukung untuk memperkaya pengalaman dan memotivasi peserta didik untuk melakukan percobaan secara interaktif dan mengembangkan aktivitas keterampilan bereksperimen. Sehingga, Lab-Vir dapat didefiniskan sebagai serangkaian program komputer yang dapat memvisualisasikan fenomena yang abstrak atau percobaan yang rumit dilakukan di laboratorium nyata, sehingga dapat meningkatkan aktivitas belajar dalam upaya mengembangkan keterampilan yang dibutuhkan dalam pemecahan masalah.

\section{Miskonsepsi}

Menurut Resser (1984) dalam Janulis P.Purba, konsep adalah suatu hubungan abstraksi yang mewakili suatu kelas objek-objek, kejadian-kejadian, kegiatan-kegiatan atau hubungan-hubungan yang mempunyai artibut yang sama. Namun demikian tafsiran perorangan terhadap banyak konsep seringkali berbeda. Misalnya penafsiran konsep "massa" tampak berbeda untuk setiap peserta didik. Tafsiran konsep adalah seseorang disebut "konsepsi". Walau dalam sains dan tekhnologi hubungannya konsep memiliki arti yang jelas yang telah disepakati oleh para ilmuwan, namun masih juga ditemukan perbedaan konsepsi peserta didik yang satu dengan yang lainnya.

\section{Aktivitas Zat Radioaktif dan Daya Tembus.}

\section{i. Aktivitas Zat Radioaktif}

Aktivitas merupakan laju peluruhan inti radioaktif. Semakin besar aktivitas, semakin banyak inti yang meluruh per satuan waktu. Dimana aktivitas A, adalah perubahan jumlah (pengurangan) inti radioaktif yang meluruh setiap satuan waktu.

$$
A=-\frac{d N}{d x}=2
$$

dengan selisih langkah matematik diperoleh

$$
N_{0}=N e^{-\lambda t}
$$

waktu paruh dapat ditentukan dengan persamaan

$$
T=\frac{0, s p s}{d}
$$

sehingga dari persamaan itu diperoleh

$$
A=A_{0}\left(\frac{1}{2}\right) \frac{t}{T}
$$

ii. Daya Tembus Sinar Radioaktif
Salah satu sifat menguntungkan dari sinar radioaktif adalah daya tembusnya yang tinggi. Kekuatan tembus sinarsinar radioaktif ini dipengaruhi oleh daya ionisasinya. Daya ionisasi adalah kemampuan sinar radioaktif menarik elektron dari atom-atom yang dilewatinya. Untuk mengionisasi atom sinar radioaktif akan menggunakan energi yang dimilikinya, sehingga semakin kuat daya ionisasinya semakin banyak energinya yang hilang.

\section{METODE PENELITIAN/EKSPERIMEN}

\section{A. Jenis Penelitian}

Penelitian ini menggunakan model four- $D$ meliputi tahap pendefinisian, perencanaaan, pengembangan, dan penyebaran. Tetapi dalam hal ini, penelitian hanya dilakukan sampai tahap pengembangan.

\section{B. Tahap Pendefinisian}

Tujuan tahap ini adalah menetapkan dan mendefinisikan syarat-syarat pembelajaran meliputi analisis awal, peserta didik, tugas, konsep, dan spesifikasi tujuan pembelajaran.

\section{Tahap Perancangan}

Tujuan tahap ini adalah untuk menyiapkan prototipe perangkat pembelajaran berbasis media Lab-Vir meliputi langkah-langkah pemilihan media, format, dan rancangan awal.

\section{Tahap Pengembangan}

Tujuan tahap ini adalah untuk menghasilkan perangkat pembelajaran yang sudah direvisi berdasarkan masukan dari pakar dan revisi setelah dilakukan uji coba.Sebelum dilakukan tahap uji coba terbatas di kelas sesungguhnya, terlebih dahulu dilakukan simulasi pembelajaran di kelas XII 2 SMAN 1 Binamu yangb berjumlah 12 orang. Simulasi dimaksudkan untuk melatih pengamat dalam mengamati aktivitas peserta didik selama proses pembelajaran.

\section{E. Subjek Penelitian}

Subjek penelitian ini adalah peserta didik kelas XII IPA 1 SMA 1 Binamu yang berjumlah 30 orang pada tahun ajaran 2013/2014.

\section{F. Instrumen Penelitian}

Instrumen yang digunakan dalam penelitian ini adalah lembar validasi perangkat pembelajaran, kuesioner evaluasi ahli media, evaluasi ahli materi, instrumen aktivitas peserta didik, angket persepsi peserta didik terhadap pembelajaran Fisika berbasis media Lab-Vir dan alat tes untuk mengetahui miskonsepsi peserta didik.

\section{G. Teknik Analisis data}

Data yang diperoleh dari penilaian ahli, dianalisis dengan melakukan coding, kemudian dideskripsikan secara kualitatif dan penggambaran data secara kontinum untuk mengetahui kategori penilaian. Selanjutnya menghitung validitas konten CVR (Content Validity Ratio) dan CVI (Content Validity Index). Penilaian valid jika CVR atau CVI berada pada kisaran nilai 0 s.d 1, sebagai berikut: 


$$
\operatorname{CVR}=\left(\mathrm{n}_{\mathrm{e}}-(\mathrm{N} / 2)\right) /(\mathrm{N} / 2) \quad(\text { Lawshe, } 1975: 567)
$$

Keterangan:

$\mathrm{n}_{\mathrm{e}}$ : Banyaknya validator yang memberikan nilai esensial (baik atau sangat baik)

$\mathrm{N}$ : Jumlah validator

Validitas setiap aspek menggunakan persamaan CVI sebagai berikut:

$$
\mathrm{CVI}=\mathrm{CVR} / \mathrm{\Sigma} \mathrm{n} \quad(\text { Lawshe, } 1975: 572)
$$

Keterangan:

$\mathrm{n}$ : Jumlah item dari setiap aspek

Jika pernyataan valid,dilanjutkan analisis releabilitas menggunakan persamaan berikut:

$\mathrm{r}_{11}=(\mathrm{k} /(\mathrm{k}-1)) \cdot\left(1-\left(\sum \sigma_{\mathrm{b}}^{2} / \sum \sigma_{\mathrm{t}}^{2}\right) \quad\right.$ (Arikunto, 2006: 196)

$\mathrm{r}_{11}:$ reliabilitas instrumen

$\mathrm{k} \quad$ : banyaknya butir pernyataan

$\sum \sigma_{\mathrm{b}}^{2}$ : jumlah variansi butir

$\sum \sigma_{t}^{2}$ : variansi total

Nilai reliabilitas yang diperoleh dikonsultasikan dengan nilai reliabilitas tabel. Instrumen dikatakan reliabel jika diperoleh reliabilitas hitung lebih besar daripada reliabilitas tabel.

\section{HASIL DAN PEMBAHASAN}

Analisis tugas dituangkan dalam LKPD yang harus diselesaikan oleh peserta didik selama proses pembelajaran .Dari tugas-tugas tersebut, peserta didik aktif melakukan percobaan virtual dan mengevaluasi pemahaman mereka tentang materi yang dipelajari.

Tahap perancangan, pemilihan dan penggunaan media berupa penggambaran keadaan yang bersifat abstrak, sesuai dengan tujuan, konsep, kondisi lingkungan dan fasilitas serta waktu yang disediakan untuk kebutuhan pembelajaran. Berbagai software yang digunakan dalam pembuatan media Lab-Vir ini yaitu AutoPlay Menu Builder untuk menampilkan autorun.exe sebagai tampilan awal saat $\mathrm{CD}$ dimasukkan ke computer dan menghiperlinkkan software untuk mengadaptasi simulasi Fisika yang diunduh dari The King's Center For Visualization in Science (KVCS) http://www.kcvs.ca. Software yang dominan digunakan adalah Autoplay untuk pengaturan tampilan program LabVir dan Camtesia V8 untuk pembuatan video tutorial.Pengembangan Lab-Vir ini dapat menyelesaikan permasalahan belajar yang dialami oleh peserta didik lebih mudah dan tidak membutuhkan biaya dan waktu yang banyak.

Program Lab-Vir yang dibuat, berisi materi yang dilengkapi dengan gambar, animasi, dan simulasi interaktif. Kelengkapan tersebut membantu peserta didik memahami konsep fisika inti dengan baik.Berikut ini, gambar 1 memperlihatkan tampilan Program Lab-Vir aktivitas zat radioaktif yang digunakan.

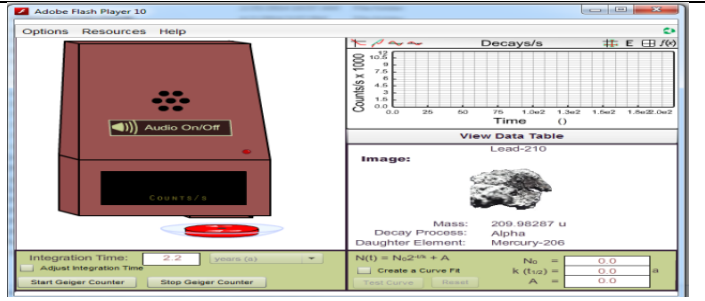

Gambar 1. Tampilan Percobaan Virtual Aktivitas zat radioaktif

Pada percobaan virtual aktivitas radioaktifkita diawali dengan memilih jenis zat radioaktif yang memiliki jenis radiasi pancaran, massa, serta unsure anak tertentu. Dengan memasukan jumlah inti awal, kita dapat menentukan hubungan antara waktu paruh dengan banyaknya inti setelah meluruh serta hubungan antara jumlah inti awal dengan jumlah inti akhir. Percobaan ini jugta dilengkapi dengan alat pendeteksi jumlah cacahan per detik, serta di lengkapi dengan hasil dalam bentuk table dan grafik

Selanjutnya, gambar 2 memperlihatkan tampilan Program Lab-Vir Daya Tembus Sinar Radiasi.

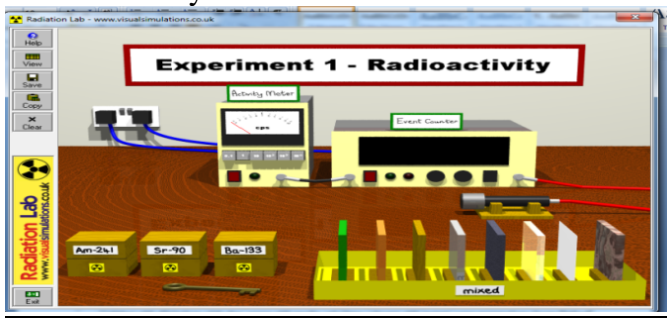

Gambar 2. Tampilan daya tembus sinar radioaktif

Percobaan virtual daya tembus radioaktif diawali dengan memilih jenis penghalang seperti copper kemudian memilih jenis sumber radiasi. Sehingga besar nuilai cacahannya dapat dilihat dengan menyalakan tombol on pada event counter serta melihat count per detik dengan menyalakan activity meter.

Pada pengembangan perangkat pembelajaran, RPP dilengkapi dengan daftar spesifikasi penting sebagai pedoman guru dalam memberikan penilaian. LKPD dilengkapi dengan materi pengantar untuk memberikan pengetahuan dasar kepada peserta didik sebelum melakukan percobaan virtual. Instrumen aktivitas peserta didik menguraikan aktivitas yang mungkin selama proses pembelajaran.

Validasi ahli dilakukan oleh dua orang ahli media sekaligus sebagai ahli materi yang merupakan dosen Fisika di Universitas Negeri Makassar. Berdasarkan penilaian perangkat pembelajaran oleh validator, diperoleh hasil valid dan reliabel untuk setiap pernyataan yang diberikan, hal ini mengindikasikan bahwa media Lab-Vir, RPP, LKPD,instrumen aktivitas, angket persepsi peserta didik serta lembar tes miskonsepsi dapat digunakan. Perangkat pembelajaran tersebut selanjutnya dapat diterapkan dalam pembelajaran di kelas, karena untuk meningkatkan pembelajaran Fisika di kelas diperlukan perangkat 
pembelajaran seperti RPP, modul dan lembar kerja peserta didik (Chodijah, et. al., 2012).

Aktivitas peserta didik pada tahap uji coba sebagai berikut:

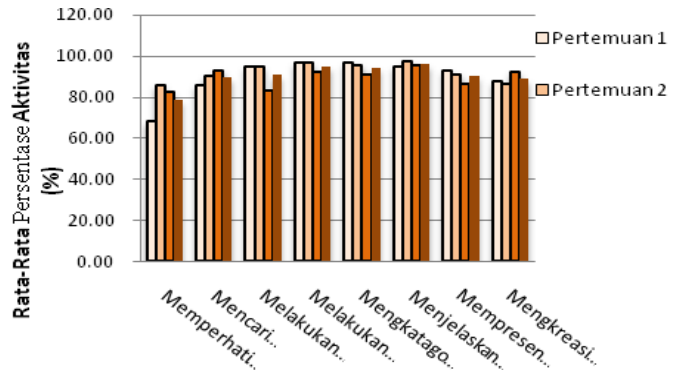

Gambar 3. Aktivitas Peserta Didik

Berdasarkan penilaian pengamat dari setiap pertemuan diperoleh bahwa aktivitas peserta didik di atas $80 \%$ yang menunjukkan bahwa pembelajaran berbasis media Lab-Vir memberikan kesempatan kepada peserta didik untuk beraktivitas. Pembelajaran berbasis media Lab-Vir memberikan kesempatan kepada peserta didik untuk bereksplorasi, sehingga sangat memungkinkan mereka untuk selalu beraktivitas, bukan hanya mendengarkan dan mencatat sebagaimana yang diungkapkan oleh Cengiz (2010) bahwa Lab-Vir disertai dengan perangkat pembelajaran yang tepat dapat melibatkan peserta didik secara aktif dalam pembelajaran.Adapun hasil analisis persepsi peserta didik terhadap pembelajaran Fisika berbasis media Lab-Vir dapat dilihat pada tabel 1 berikut:

Tabel 1. Hasil Analisis Persepsi Peserta Didik

\begin{tabular}{clc}
\hline No. & \multicolumn{1}{c}{ Indikator } & $\begin{array}{c}\text { Rerata } \\
\text { Persentase (\%) }\end{array}$ \\
\hline 1 & Fasilitas Lab-Vir Model Presentasi & 92,5 \\
\hline 2 & Fasilitas Lab-Vir Model Tutorial & 90,8 \\
\hline 3 & $\begin{array}{l}\text { Daya Tarik } \\
\text { Menggunakan Melajar dengan } \\
\text { Model Presentasi dan Tutorial }\end{array}$ & 94,5 \\
\hline 4 & $\begin{array}{l}\text { Aktivitas Bab-Vir } \\
\text { Menggunakan Media dengan } \\
\text { Model Presentasi dan Tutorial }\end{array}$ \\
\hline \multicolumn{4}{c}{ Rata-Rata } \\
\hline
\end{tabular}

Berdasarkan tabel 1, diperoleh persepsi peserta didik terhadap pembelajaran Fisika berbasis media Lab-Vir di atas 90\% yang menunjukkan bahwa peserta didik sangat setuju terhadap pembelajaran yang dilakukan.

Persepsi peserta didik setelah belajar dengan menggunakan media Lab-Virmenunjukkan hasil yang sangat setuju, tidak ada peserta didik yang memberikan penilaian tidak setuju dari setiap kriteria yang diajukan. Peserta didik tertarik dengan tampilan simulasi media pembelajaran, mudah dalam menjalankan simulasi interaktif, mudah memahami materi pelajaran, serta senang belajar dengan bantuan media Lab-Vir. Hal ini sesuai dengan penelitian Yulianti, et. al., (2012) bahwa penerapan pembelajaran berbasis Lab-Vir dapat meningkatkan kemampuan afektif peserta didik yang menggambarkan perasaan, minat, dan sikap terhadap proses pengajaran. Selanjutnya, Daesang, et. al., (2013) bahwa persepsi peserta didik berdampak terhadap kinerja. Semakin baik persepsi mereka terhadap pembelajaran, maka semakin baik pula kinerja mereka. Penggunaan media yang tepat dapat meningkatkan persepsi peserta didik sehingga mereka termotivasi dalam belajar.

Meskipun hasil penelitian ini menunjukkan persepsi dan aktivitas peserta didik dalam katagori sangat setuju dan baik, mencakup aktivitas memperhatikan demonstrasi, mencari konsep, melakukan perhitungan, mengkatagorikan, menjelaskan, mempresentasikan, dan mengkreasikan proses. Tidak diklaim bahwa percobaan virtual lebih efektif dibandingkan dengan percobaan di laboratorium nyata. Sebaliknya, percobaan virtual dilakukan dengan alasan keterbatasan alat, pertimbangan waktu, materi pelajaran yang abstak, maupun pertimbangan bahaya yang dapat ditimbulkan jika dilakukan percobaan nyata di laboratorium seperti efek radiasi bagi kesehatan.

\section{KESIMPULAN}

Karakteristik media Lab-Vir menghasilkan dua konsep yaitu aktivitas radioaktif dan daya tembus. Selain itu, media Lab-Vir yang dikembangkan berbentuk program pembelajaran dengan tiga menu utama di setiap pembahasan yaitu kompetensi, pendahuluan, dan percobaan virtual. Karakteristik perangkat pembelajaran berbasis media LabVir meliputi RPP, LKPD dirancang dengan maksud memadukan sesi kelas dengan sesi percobaan menggunakan Lab-Vir. Materi terkait dalam percobaan virtual disertakan dalam perangkat pembelajaran yang dapat dipelajari secara mandiri oleh peserta didik.

Aktivitas peserta didik di atas 85\%, menunjukkan pembelajaran yang dilakukan mampu mengaktifkan peserta didik. Persentase persepsi peserta didik adalah 93,5\% menunjukkan sangat setuju terhadap pembelajaran Fisika berbasis media Lab-Vir.

\section{PUSTAKA}

[1] Arikunto, S. (2006). Prosedur Penelitian: Suatu Pendekatan Praktik. Jakarta: Rineka Cipta

[2] B \& Peter Mahaffy. (2012). The King's Centre for Visualization in Science. (online). (http://www.kcvs.ca, Diakses 1 Oktober 2012)

[3] Cengiz, T. (2010). The Effect of the Virtual Laboratory on Students' Achievement and Attitude in Chemistry. International Online Journal of Educational Sciences, 2 (1), $37-53$

[4] Chodijah, St., Ahmad Fauzi., \&Ratna Wulan. (2012).Pengembangan Perangkat Pembelajaran FisikaMenggunakan Model Guided Inquiry yang Dilengkapi Penilaian Portofolio pada Materi Gerak Melingkar. Jurnal Pendidikan Fisika Indonesia, 1 (2), 1-19

[5] Daesang, K., Dong-Joong K., \&Woo-Hyung W. (2013). Cognitive Synergy in Multimedia Learning. International Education Studies, 6 (4), 76-84

[6] Gundogdu, K., Silman, F., \&Ozan, C. (2011).A Comparative Study on Perception of Teachers on the Use of Computers in Elementary Schools of Turkey and T.R.N.C. International Online Journal of Educational Sciences, 3 (1), 113-137 
Materi Fisika Inti di SMAN 1 Binamu, Jeneponto

[7] Kutluca, T. (2010). Investigation of Teachers' Computer Usage Profiles and Attitudes toward Computers International Online Journal of Educational Sciences, 2 (1), 81-97

[8] Lawshe, C.H. (1975). A Quantitative Approach to Content Validity. Chicago: Personnel Psychology

[9] Tatli, Z \& Ayas, A. (2012).Virtual Chemistry Laboratory: Effect Of Constructivist Learning Environment. Turkish Online Journal of Distance Education, 13 (1), 183 - 199

[10] Yulianti, D., Khanafiyah, S., \&Sugiyanto.(2012).Penerapan Virtual Experiment Berbasis Inkuiri untuk Mengembangkan Kemandirian Mahasiswa. Jurnal Pendidikan Fisika Indonesia, 8 (2), 127-134 